Articles in the December issue are:

"On the Magnetic Field of the Earth," by L. Steiner.

"'The Physical Theory of the Earth's Magnetic and Electric Phenomena, No. IV.,' by L. A. Bauer.

"Atmospheric Electricity Observations on the Second Cruise of the Carnegie from New York to Colombo," by E. Kidson.

"On the Normal Magnetic Elements at the Mauritius Magnetic Observatory,' by L. A. Bauer.

\section{TREMATODE GENERIC NAMES PROPOSED FOR THE "OFFICIAL LIST OF ZOOLOGICAL NAMES",}

1. The International Commission on Medical Zoology, appointed by the Graz International Zoological Congress, has made its first report on the names of Trematode genera parasitic in man.

2. Four members, namely, Blanchard (Paris), Monticelli (Naples), Stiles (Washington) and Zschokke (Basel), unanimously agree that the following eleven names are from the present standpoint of systematic zoology and nomenclature, the correct names for the genera in question, and that the species cited as genotypes are the correct types according to the International Rules of Zoological Nomenclature.

Clonorchis Looss, 1907, Feb. 1, 147-152, type sinensis.

Dicrocolium Dujardin, 1845a, 391, type lanceatum = lanceolatum ( $=\$$ dendriticum sub judice).

Fasciola Linnæus, 1758a, 644, 648-649, type hepatica.

Fasciolopsis Looss, 1899b, 557, 561, type buskii (seu buski teste Blanchard).

Gastrodiscus Leuckart in Cobbold, 1877e, 233-239, type sonsinoii (seu sonsinoi teste Blanchard).

Heterophyes Cobbold, 1866a, 6, type agyptiaca $=$ heterophyes.

Metorchis Looss, 1899b, 564-566, type albidus.

Opisthorchis Blanchard, 1895f, 217, type felineus.

Paragonimus Braun, 1899g, 492, type westermanii (seu westermanni teste Blanchard).

Pseudamphistomum Luehe, 1908, 428-436, type truncatum.

Watsonius Stiles \& Goldberger, 1910, 212, type watsoni.
3. The following commissioners have not voted: Jaegerskioeld (Gothenburg), Looss (Cairo), Luehe (Koenigsberg), Pintner (Vienna) and Shipley (Cambridge).

4. Notice is hereby given that the undersigned will wait until July 1, 1912, for any zoologist to raise objection to any portion of this report, and that on that date all names to which valid objection is not raised will be forwarded to the International Commission on Zoological Nomenclature with the motion that these names be included in the "Official List of Zoological Names" provided for by the Graz Zoological Congress.

5. All correspondence on this subject should be addressed to $\quad$ C. W. Stiles, Secretary International Commission on Zoological Nomenclature

Hygienic Laboratory,

Washington, D. C.,

November 11, 1911

\section{SPECIAL ARTICLES}

NOTES UPON CRONARTIUM RIBICOLA ${ }^{1}$

A NUMBER of new points have been worked out in connection with this fungus during the past year. A coarse yellow mottling of pine needles and of the bark on the twigs and leader occurs rarely, but is very characteristic when it does occur. It seems to occur only in trees which have had the disease for more than one year. It has developed in the greenhouse upon plants which were known to be infected and has been found in one lot of trees set out in the field.

In 1910 an attempt was made by the speaker to pick out all the infected trees in a lot of 10,000 three-year-old white pines. The remainder were then planted out by state authorities in a large open field where every tree could be easily found the next year, and in a locality where Ribes were absent for a considerable distance. An examination the next summer showed a considerable number which had swellings of the bark, but none were found with fruiting bodies of the Perider-

1 Presented before the American Phytopathological Society, December, 1911. 
mium. This, together with other experience along similar lines, convinced the speaker that the best single inspection possible will not remove all infected trees from a diseased lot. There will be at least a few hold-over cases which will develop afterward. This makes repeated inspection absolutely necessary and such repeated inspections very soon cost more than the value of the entire lot of trees. In most cases it will be real economy to pull up the trees and burn them at once.

The speaker, in cooperation with the state authorities, discovered the disease for the first time in the states of New Jersey and Virginia in 1911. In the former case the entire lot was destroyed by the owner, while the action taken in the latter is not known. No fruiting bodies were found in Virginia, but the swollen stems were present in a few cases. During the past year the disease has been shipped to us by a French firm and inquiry showed that they raised their trees themselves.

The finding of the teleuto stage of the fungus affecting the stipule and bracts of a Ribes leaf in the greenhouse, is believed to practically prove that the fungus may sometimes attack the bud scales of dormant bushes and cuttings; this very probably explains the anomalous appearance of this fungus in this country upon Ribes at Geneva, N. Y., and possibly in Kansas.

The single German nursery of J. Heins's Sons has sent us over 95 per cent. of the total amount of diseased stock that has been found in this country, yet they say they have no disease in their nursery. Barely a month ago the writer received samples of their white pine stock, which had just been submitted to the superintendent of the New York State Forests by Heins's Sons, and one at least had visible swelling of the stem, which the writer is confident is caused by the blister rust. This shows that he was correct in his former suspicion that they do not know the field characters' of this disease. Inoculations have been successfully made by the writer with spores from diseased white pine trees sent by $J$. Heins's Sons to Lake Clear Junction and Salamanca, New York, and to the states of New Jersey and Connecticut, upon Ribes in the greenhouse. The shipments thus tested were made in 1908, 1909 and 1910.

Experience with greenhouse inoculations on Ribes shows that the teleuto stage develops only after the cool weather of autumn sets in: that is, the uredo stage flourishes through the summer, but the teleuto stage does not appear until cooler weather prevails. The experiments for two years agree in showing this peculiarity. Greenhouse inoculations have been made upon young Pinus strobus with teleutospores secured by inoculation on Ribes americanum with æcidiospores borne upon imported trees of Pinus strobus. Inoculations thus made in November, 1910, are now beginning to give results. One each of the trees inoculated with wounds and without wounds is now showing slight swelling such as is so characteristic of the blister rust disease.

Perley Spaulding

$$
\begin{aligned}
& \text { Office of Forest Pathology, } \\
& \text { Bureau of Plant Industry, } \\
& \text { U. S. Department of Agriculture }
\end{aligned}
$$

\section{THE BOTANICAL SOCIETY OF AMERICA}

THE annual meeting of the Botanical Society of America was held at the Business High School, Washington, D. C., December 27 to 29, 1911.

The following were elected officers for the ensuing years:

President-L. R. Jones, University of Wisconsin. Vice-president-B. M. Duggar, Cornell University.

Secretary-G. T. Moore, Washington University.

Councilor-Wm. Trelease, Missouri Botanical Garden.

These, with Arthur Hollick, treasurer, and C. L. Shear and R. A. Harper, councilors, constitute the council for 1912.

The following associate members were elected to full membership: D. H. Campbell, Stanford University; M. L. Fernald, Harvard University; J. B. Overton, University of Wisconsin; P. H. Rolfs, Florida Experiment Station; P. A. Rydberg, New York Botanical Garden.

Botanists elected to associate membership were: I. W. Bailey, Harvard University; F. S. Collins, Malden, Mass.; C. W. Edgerton, Louisiana Experiment Station; J. H. Faul, University of Toronto; R. McM. Harper, University of Alabama; H. Hasselbring, Bureau of Plant Industry; C. E. 